\title{
Nitrogen and sulphur deposition and the growth of Sphagnum fuscum in bogs of the Athabasca Oil Sands Region, Alberta
}

\author{
R. Kelman WIEDER*, Dale H. VITT ${ }^{1)}$, Medora BURKE-SCOLL, Kimberli D. SCOTT, Melissa HOUSE ${ }^{1)}$ \\ and Melanie A. VILE \\ Department of Biology, Villanova University, Villanova, PA 19085, USA \\ ${ }^{1)}$ Department of Plant Biology, Southern Illinois University, Carbondale, IL 62901,USA \\ *e-mail corresponding author: kelman.wieder@villanova.edu
}

\begin{abstract}
One of the consequences of ongoing development of the oil sands reserve in the Athabasca Oil Sands Region (AOSR) near Fort McMurray, Alberta, Canada $\left(56^{\circ} 39^{\prime} \mathrm{N}, 111^{\circ} 13^{\prime} \mathrm{W}\right)$ is an increase in emissions of nitrogen (N) and sulphur (S), with an attendant increases in regional atmospheric $N$ and $S$ deposition. Regional land cover across northeastern Alberta is a mixture of Boreal Mixedwood, Boreal Highlands, and Subarctic areas. Peatlands occupy between 22 and 66\% of these natural regions, and the land cover of bogs varies between $6.7 \%$ in the Mixedwood Region to 46\% in the Subarctic Region. Ombrotrophic bog ecosystems may be especially sensitive to atmospheric deposition of $N$ and $S$. Across 10 ombrotrophic bog sites in the AOSR over four years (20052008), we found no evidence of elevated deposition of $\mathrm{NH}_{4}{ }^{+}-\mathrm{N}, \mathrm{NO}_{3}{ }^{-}-\mathrm{N}$, total inorganic nitrogen $\left(\mathrm{TIN} ; \mathrm{NH}_{4}{ }^{+}-\mathrm{N}\right.$ plus $\left.\mathrm{NO}_{3}{ }^{-} \mathrm{N}\right)$, or $\mathrm{SO}_{4}{ }^{2-}-\mathrm{S}$, with values measured using ion exchange resin collectors averaging $0.61 \pm 04,0.20 \pm 0.01,0.81 \pm 0.04$, and $1.14 \pm 0.06 \mathrm{~kg}$ $h a^{-1} y^{-1}$, respectively. Vertical growth and net primary production of Sphagnum fuscum, an indicator of elevated deposition, did not differ consistently across sites, averaging $11.8 \pm 0.2 \mathrm{~mm} y^{-1}$ and $234 \pm 3.3 \mathrm{~g} \mathrm{~m}^{-2} \mathrm{y}^{-1}$, respectively, over the four years. Neither vertical growth nor net primary production of S. fuscum was correlated with growing season atmospheric $N$ or $S$ deposition. Our data provide a valuable benchmark of background values for monitoring purposes in anticipation of increasing $N$ and $S$ deposition over a broader geographic region within the AOSR.
\end{abstract}

Key words: Sphagnum fuscum, nitrogen deposition, sulphur deposition, Athabasca Oil Sands Region, peatland, bog, Canada

\section{INTRODUCTION}

The boreal forest of western Canada consists of a mosaic of plant communities, including evergreen forests, deciduous forests, treed bogs, open and shrubby fens, emergent marshes, lakes, and streams. Within this mosaic, peatlands form an important component, occupying $166,300 \mathrm{~km}^{2}$ or about $16 \%$ of the provincial area of Alberta (Vitt et al. 1996). The oil sands region of northeastern Alberta is a mixture of Boreal Mixedwood, Boreal Highlands, and Subarctic areas (AEP 1994). Peatlands occupy between 22 and $66 \%$ of these natural regions, and the land cover of bogs varies between $6.7 \%$ in the Mixedwood Region to $46 \%$ in the Subarctic Region (Vitt et al. 1996).

Continental bogs are ombrogenous peatlands receiving nutrients, minerals, and water only from precipitation (see Wieder \& Vitt 2006; Vitt 2008 for reviews). Bogs are acidic owing primarily to dissociation of weak organic acids produced through decomposition processes and from the production of new cation exchange sites on the cell walls of each year's new growth of Sphagnum (Hemond 1980). The acidity may contribute to the low species richness and Sphagnum dominance of bogs. In continental areas, the dominant species of Sphagnum is $S$. fuscum, a species that forms densely packed communities of desiccation-avoiding plants. Sphagnum fuscum is rich in polyphenols and as such is resistant to decomposition (Turetsky et al. 2008). All of these qualities lead to the ability of this species to form relatively high hummocks that rise from 0.5 to $1 \mathrm{~m}$ above the bog water table. Continental bogs in North America typically have open tree canopies of only one species - Picea mariana. S. fuscum hummocks commonly occur in open areas not overtopped by $P$. mariana branches; these hummocks receive atmospheric deposition, with a chemical composition that has not been altered by dry deposition onto needle surfaces and/or canopy exchange.

The ombrogenous nature of bogs makes them model ecosystems for studying the effects of atmospheric pollution. Sphagnum fuscum is the foundational species in these nutrient poor bogs and is an excellent indicator of ecosystem performance (Vitt 2006; Vile et al., in press). Bogs generally are N-limited (Walbridge \& Navaratnam 2006; Wieder 2006), and this may be especially true in areas like continental western Canada, where atmospheric $\mathrm{N}$ deposition is quite low (about $1 \mathrm{~kg} \mathrm{ha}^{-1} \mathrm{y}^{-1}$; Vitt et al. 2003). Interest in the responses of bogs to elevated $\mathrm{N}$ deposition grew following studies that implicated high atmospheric $\mathrm{N}$ deposition as a causal factor in the decline in Sphagnum in bogs of the United Kingdom (Woodin et al. 1985; Press et al. 1986). A synthesis of the large body of research on $\mathrm{N}$ deposition 
effects in peatlands, and in particular Sphagnum, led to the formulation of a conceptual framework that the response of Sphagnum to increasing $\mathrm{N}$ deposition is triphasic (Lamers et al. 2000). At low $\mathrm{N}$ deposition $(<12$ $\left.k g h^{-1} y^{-1}\right)$, atmospheric inputs enhance net primary production (NPP) of N-limited Sphagnum mosses. As N deposition increases to the point where Sphagnum NPP is no longer $\mathrm{N}$-limited, the excess $\mathrm{N}$ may be taken up by growing mosses resulting in an increase in tissue $\mathrm{N}$ concentrations within the Sphagnum canopy (12-18 $\mathrm{kg} \mathrm{ha}^{-1}$ $\left.\mathrm{y}^{-1}\right)$. As atmospheric $\mathrm{N}$ deposition increases beyond the point where the Sphagnum canopy is saturated with $\mathrm{N}$ $\left(>18 \mathrm{~kg} \mathrm{ha}^{-1} \mathrm{y}^{-1}\right)$, dissolved inorganic $\mathrm{N}$ may pass through the Sphagnum canopy into the underlying peat. A possible consequence of elevated atmospheric $\mathrm{N}$ deposition is a decrease the C:N ratio of Sphagnum mosses and peat, stimulating decomposition and the associated release of $\mathrm{CO}_{2}$ to the atmosphere (Lamers et al. 2000; Berendse et al. 2001; Limpens \& Berendse 2003; Limpens et al. 2006).

Sphagnum peatlands also appear to be affected by atmospheric deposition of inorganic $\mathrm{S}$ compounds (Vile $\&$ Novák 2006). The disappearance of Sphagnum groundcover from peatlands in the British Pennines was attributed to elevated atmospheric S deposition (Ferguson et al. 1978; Ferguson \& Lee 1979, 1980). In addition, stimulation of anaerobic dissimilatory sulphate reduction by elevated sulphate deposition may have implications for the functioning of bogs as net sinks for atmospheric carbon (Wieder et al. 1990; Vile et al. 2003a,b; Gauci et al. 2002, 2004, 2006). Alberta bogs receive low atmospheric S deposition, at about $0.5 \mathrm{~kg} \mathrm{~S}$ ha $^{-1} \mathrm{y}^{-1}$ (Vile et al. 2003a).

One of the consequences of ongoing development of the oil sands reserve in the Athabasca Oil Sands Region (AOSR) near Fort McMurray (56 $36^{\circ} \mathrm{N}$, $111^{\circ} 13^{\prime} \mathrm{W}$ ) is an increase in emissions of nitrogen $(\mathrm{N})$ and sulphur (S), with attendant increases in regional atmospheric $\mathrm{N}$ and $\mathrm{S}$ deposition (Taylor 1981; EPCM 2002). Between 1980 and 1995, activities in the region released nitrogen oxides $\left(\mathrm{NO}_{\mathrm{x}}\right)$ to the atmosphere at a rate of 36 to $60 \mathrm{t} \mathrm{d}^{-1}($ CEMA NO $\mathrm{SO}_{2}$ Management Working Group 2005). Estimates for 2010 (and beyond) predict increasing development in the region, with attendant increases in emissions of $\mathrm{NO}_{\mathrm{x}}$ up to a potential discharge of approximately 355 tons per day $\left(\mathrm{t} \mathrm{d}^{-1}\right)$. Current emissions of $\mathrm{SO}_{2}$ are about $300 \mathrm{t} \mathrm{d}^{-1}$, and estimates of future emissions range from 350 to $400 \mathrm{t} \mathrm{d}^{-1}$ by 2015 (CEMA NO $\mathrm{SO}_{2}$ Management Working Group 2005 from Golder 2003 data).

Given the sensitivity of Sphagnum mosses to elevated atmospheric $\mathrm{N}$ and $\mathrm{S}$ deposition, bogs in the AOSR provide an opportunity for monitoring and serving as early warning indicators of ecosystem dysfunction. Here we report on four years (2005-2008) of atmospheric $\mathrm{N}$ and $\mathrm{S}$ deposition data for 10 sites in the
AOSR along with the growth response of the foundational bog moss species, Sphagnum fuscum, to assess both the potential impact of $\mathrm{N}$ and $\mathrm{S}$ deposition and any critical ecosystem response.

\section{METHODS}

\subsection{Study sites}

Ten bog sites associated with lakes were selected from a set of 50 lakes that form the basis for the Province of Alberta's Regional Aquatics Monitoring Program (RAMP), charged with determining, evaluating, and communicating the state of the aquatic environment and any changes that may result from cumulative resource development within the Regional Municipality of Wood Buffalo, Alberta (www.ramp-alberta.org). Our study sites were located in four geographical areas within the AOSR: the Birch Mountains (BM; Subarctic Natural Region; 3 bogs), northeast of Fort McMurray, (NE; Central Mixedwood Natural Region; 3 bogs), the Stony Mountains, (SM; Boreal Highlands Natural Region; 3 bogs), and west of Fort McMurray (WF; Central Mixedwood Natural Region; 1 bog) (Fig. 1).

All of the sites are ombrotrophic and dominated by a set of species characteristic of Alberta bogs (Belland \& Vitt 1995; Vitt et al. 1995). The tree layer is composed only of Picea mariana; shrubs are Ledum groenlandicum and Vaccinium vitis-idaea, the field layer consists of Rubus chamaemorus, Smilacina trifolia, and Oxycoccus microcarpus; Eriophorum vaginatum is occasionally present. Bryophytes and lichens make up 100\% cover of the ground layer. The dominant species of bryophyte is Sphagnum fuscum, with S. magellanicum, S. angustifolium, Pleurozium schreberi, and Aulacomnium palustre occurring sporadically. Sphagnum fuscum often has Pohlia nutans and Leiomylia anomala occurring epiphytically. Cladina mitis and several species of Cladonia are also sporadic. Hummocks are well developed, varying from $0.5-1.0 \mathrm{~m}$ above the wetter hollows. Bogs in this region of Alberta have $\mathrm{pH}$ 's in the range of 3.0-4.5 with spring water level at or just below the wettest hollows (Vitt 2000).

Mean annual temperature and total annual precipitation for Fort McMurray are $0.7^{\circ} \mathrm{C}$ and $456 \mathrm{~mm}$, respectively. During the 4-year study, monthly temperatures tracked long-term means, with 2005 and 2006 being warmer than average because of a warm 2005-2006 winter and 2008 being cooler than average because of a cool winter and spring (Fig. 2). Annual precipitation was considerably lower than average in 2007, reflecting a dry spring and autumn.

\subsection{Sphagnum fuscum growth}

Growth of Sphagnum fuscum was measured using the cranked wire method (Clymo 1970; Vitt 2007). At each site, we placed 20 wires in each of 3 S. fuscum hummocks (except at SM8, where we placed 40 wires in each of 3 hummocks). 


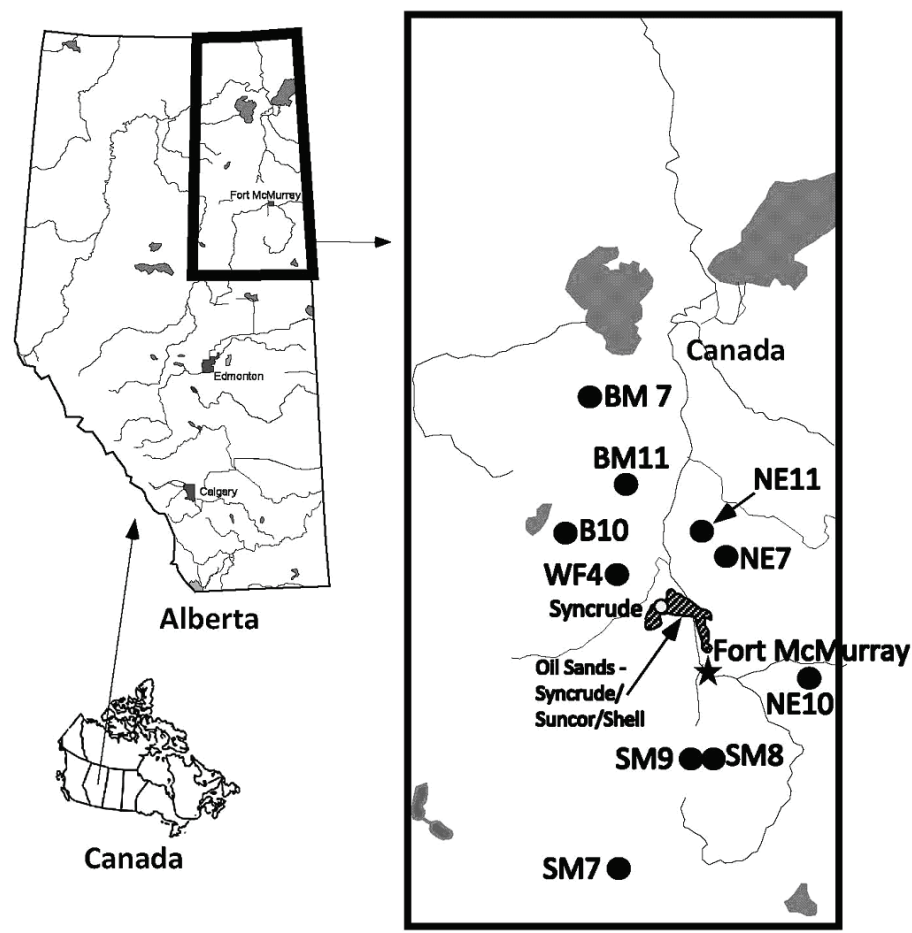

Fort McMurray Area

Fig. 1. Location of Fort McMurray, Alberta, Canada and of the 10 bog study sites surrounding Fort McMurray in the Birch Mountains (BM), northeast/east of Fort McMurray (NE), the Stony Mountains (SM), and west of Fort McMurray (WF).
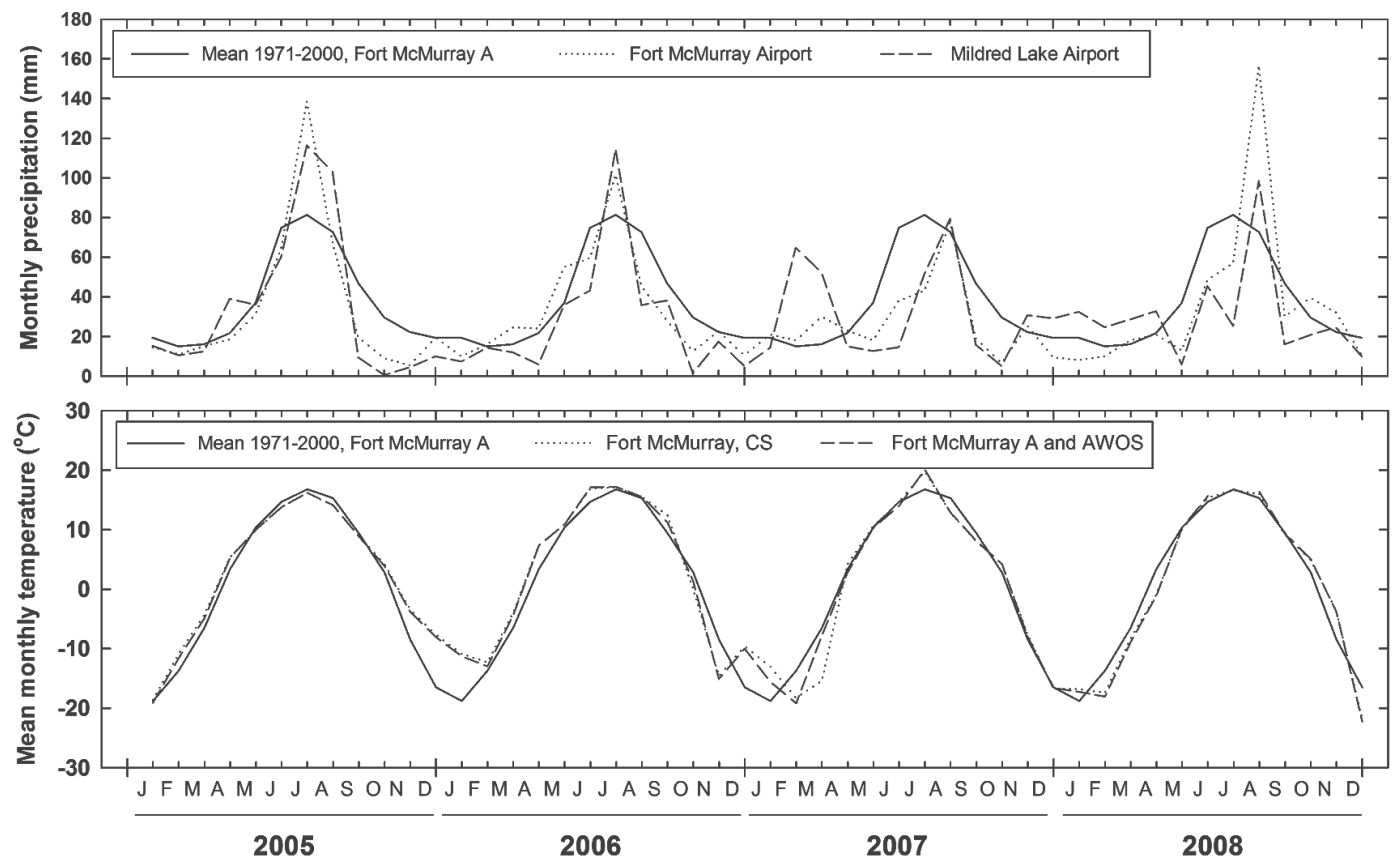

Fig. 2. Monthly precipitation and temperature in the Fort McMurray area. Data are from: Canadian Climate Normals, 1971-2000 (20-year averages from 1971-2000; www.climate.weatheroffice.ec.gc.ca/climate_normals/index_e.html); The Weather Network, Historical Data (precipitation for Mildred Lake and the Fort McMurray airport; www.theweathernetwork.com); and the National Climate Data and Information Archive (precipitation at Fort McMurray A and temperature data from Fort McMurray A, CS, and AWOS stations, www.climate.weatheroffice.ec.gc.ca). For 2005, 2006, 2007, 2008 (averages of the 2 weather stations), and the 20year average (1971-2000 for Fort McMurray A station), total annual precipitation was 415, 370, 357, 404, and 456 mm, respectively, and mean annual temperature was $2.2,2.3,0.3,-0.5$, and $0.7^{\circ} \mathrm{C}$ respectively. 


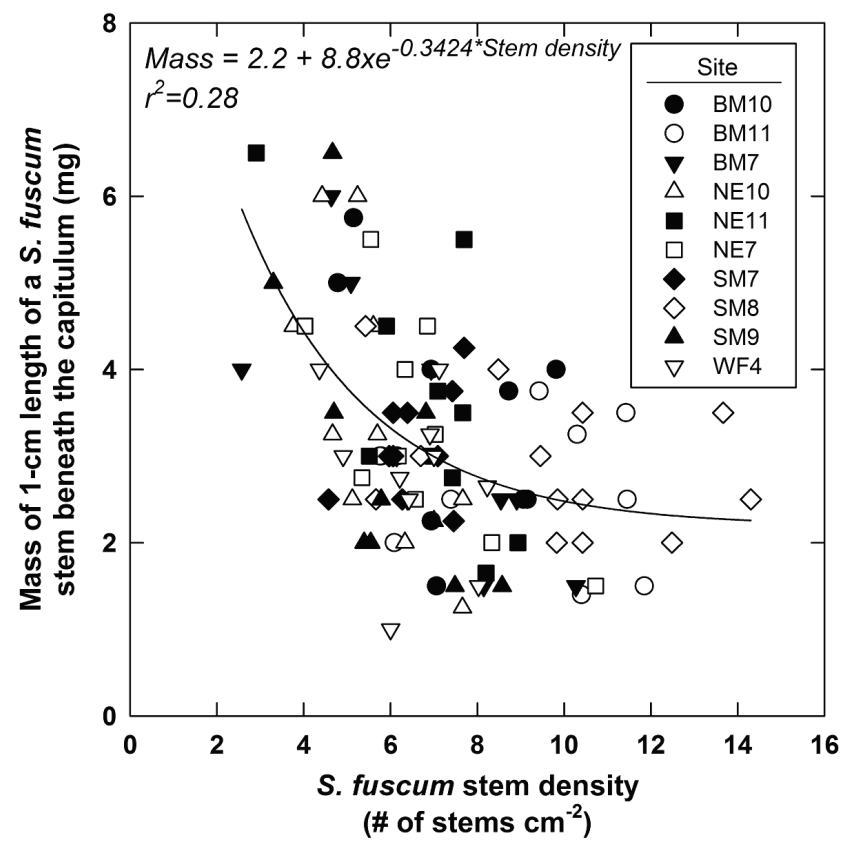

Fig. 3. Relationship between the mass of the $1 \mathrm{~cm}$ length of individual $S$. fuscum stems beneath the moss capitulum and $S$. fuscum stem density (number of stems $\mathrm{cm}^{-2}$ ). Each plotted point represents data from an individual sample from a $S$. fuscum hummock.

Wires were set extending to a uniform height above the peat early in the growing season when $S$. fuscum hummocks were nearly frost-free (24-25 May 2005; 10 11 June 2006; 21 May 2007; 29-30 May 2008 and were re-measured at the end of the growing season (26-27 September 2005; 9-10 October 2006; 4-5 October 2007; 1 October 2008), allowing for quantification of vertical growth.

To convert vertical growth measurements to NPP, at the end of each growing season, an intact core $(6.5 \mathrm{~cm}$ diam., $5 \mathrm{~cm}$ deep) of the Sphagnum fuscum canopy was collected from each hummock where cranked wires had been inserted. In each sample, we counted the total number of Sphagnum plants. Subsequently, 20 individual $S$. fuscum stems were randomly selected from each sample, the capitula were removed (new vertical growth occurs by extension of the plant stem beneath the capitulum), and the underlying $2 \mathrm{~cm}$ of stems were dried at $90{ }^{\circ} \mathrm{C}$ for 48 hours and weighed to determine stem mass density. Multiplication of plant densities (number of $S$. fuscum stems $\left.\mathrm{cm}^{-2}\right)$ by stem mass densities $\left(\mathrm{g} \mathrm{cm}^{-1}\right.$ of stem) yields bulk density of newly produced biomass $\left(\mathrm{g} \mathrm{cm}^{-3}\right)$, which when multiplied by growth in length $\left(\mathrm{cm} \mathrm{y}^{-1}\right)$ yields NPP $\left(\mathrm{g} \mathrm{cm}^{-2} \mathrm{y}^{-1}\right)$. We used site mean bulk density values to calculate NPP from linear growth measurements.

\section{3. $N$ and $S$ deposition}

We quantified deposition of $\mathrm{NH}_{4}^{+}-\mathrm{N}, \mathrm{NO}_{3}^{-}-\mathrm{N}$ and $\mathrm{SO}_{4}{ }^{2-}-\mathrm{S}$ using ion exchange resin collectors (Fenn \& Poth 2004), increasing the number of collectors per site from 3 to 5 beginning in June 2006 because of loss of samplers from animal damage. We initially used $10 \mathrm{~cm}$ diameter funnels, changing to $19 \mathrm{~cm}$ diameter funnels in October 2007 to conform with the updated design recommendations of Fenn et al. (undated). Snow tube extensions $(50 \mathrm{~cm}$ tall) were used over the non-growing season. Collectors were placed in open areas, attached to sawed-off black spruce trees, about $1.0 \mathrm{~m}$ above the peat surface. In the lab, we submersed resins in $40 \mathrm{~mL}$ of $2 \mathrm{M} \mathrm{KCl}$ and rinsed with additional $10 \mathrm{~mL}$ of $2 \mathrm{M}$ $\mathrm{KCl}$. Extract solutions were analyzed for $\mathrm{NH}_{4}{ }^{+}-\mathrm{N}$ (phenate method), $\mathrm{NO}_{3}{ }^{-} \mathrm{N}$ (hydrazine reduction method), and $\mathrm{SO}_{4}{ }^{2-}-\mathrm{S}$ (methylthymol blue method) on a Technicon AutoAnalyzer II for the first 5 collection dates and subsequently on a Lachat QuikChem Automated Flow Injection Ion Analyzer. For each collection period, 3-5 replicate batches of resin that were not placed in the field were extracted as blanks; mean values for blanks were subtracted from values for resins that had been placed in the field.

\section{RESULTS}

Bulk densities of newly produced $S$. fuscum biomass averaged $0.021 \pm 0.001 \mathrm{~g} \mathrm{~cm}^{-3}$, with the only significant site difference between SM8 $\left(0.027 \pm 0.002 \mathrm{~g} \mathrm{~cm}^{-3}\right)$ and SM9 $\left(0.016 \pm 0.002 \mathrm{~g} \mathrm{~cm}^{-3}\right)$. We found an inverse relationship between the mass of the individual S. fuscum stems $1 \mathrm{~cm}$ beneath the capitulum and the number of $S$. fuscum stems per $\mathrm{cm}^{2}$, the two terms that enter into the bulk density calculations (Fig. 3). This inverse relationship reflects considerable variation within and between hummocks and sites in S. fuscum stem mass and the number of stems per area, which in combination leads to rather consistent bulk density values. 

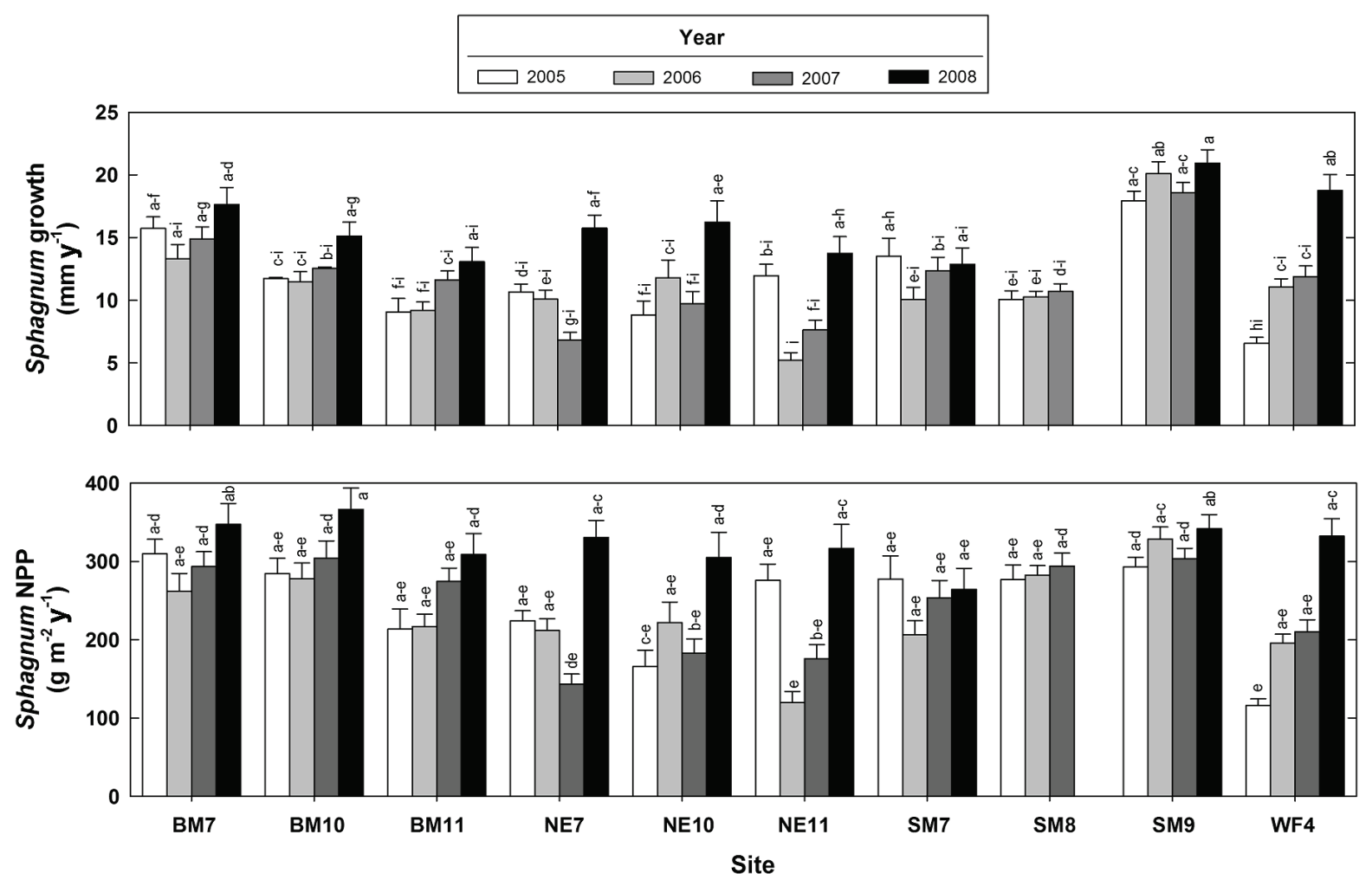

Fig. 4. Sphagnum fuscum vertical growth (top panel) and NPP (bottom panel). Values are means \pm standard errors ( $\mathrm{n}=53-60$ except at SM8 where $\mathrm{n}=121$ ). Data were analyzed using a repeated measures ANOVA (repeated measurements on each cranked wire); $a$ posteriori comparisons to characterize the site $\mathrm{x}$ year interaction were conducted using Tukey's Honestly Significant Difference test. Means with the same letter above the error bars do not differ significantly. No data for site SM8 in 2008.

Both linear growth of Sphagnum and Sphagnum NPP exhibited a significant site by year interaction $(p$ $<0.0001)$, indicating no consistent differences between sites or between years (Fig. 4). Overall, linear growth averaged $11.8 \pm 0.2 \mathrm{~mm} \mathrm{y}^{-1}$ and NPP averaged $234 \pm$ $3.3 \mathrm{~g} \mathrm{~m}^{-2} \mathrm{y}^{-1}$ (means \pm standard errors, $n=2448$ ).

Mean daily deposition of $\mathrm{NH}_{4}{ }^{+}-\mathrm{N}$, TIN $\left(\mathrm{NH}_{4}{ }^{+}-\mathrm{N}\right.$ plus $\mathrm{NO}_{3}{ }^{-}-\mathrm{N}$ ), and $\mathrm{SO}_{4}{ }^{2-}-\mathrm{S}$ was significantly greater during the growing season than during the rest of the year; this pattern was not consistent across all sites for $\mathrm{NO}_{3}{ }^{-}-\mathrm{N}$ deposition (Fig. 5). Although there were some differences between sites in mean daily deposition of $\mathrm{NH}_{4}{ }^{+}-\mathrm{N}$ and TIN that were consistent across all sampling periods, no pattern is evident between the four regions (BM, NE, SM, WF). Mean daily $\mathrm{SO}_{4}{ }^{2-}-\mathrm{S}$ and $\mathrm{NO}_{3}^{-}-\mathrm{N}$ deposition did not differ between sites. Overall mean weighted (by the number of days in each collection period) deposition of $\mathrm{NH}_{4}{ }^{+}-\mathrm{N}, \mathrm{NO}_{3}{ }^{-}-\mathrm{N}$, TIN, and $\mathrm{SO}_{4}{ }^{2-}-\mathrm{S}$ was $166 \pm 10,54 \pm 2,221 \pm 11$, and $311 \pm 16$ $\mu \mathrm{g} \mathrm{m}^{-2} \mathrm{~d}^{-1}$, respectively, equivalent to annual deposition values of $0.61 \pm 0.04,0.20 \pm 0.01,0.81 \pm 0.04$, and 1.14 $\pm 0.06 \mathrm{~kg} \mathrm{ha}^{-1}$, respectively.

Mining of oil sands in the Fort McMurray area began at the site in 1973, with the first barrel of oil shipped five years later. Using the Syncrude mine site facilities as a reference location, we found no significant relationships between distance from Syncrude (Tab. 1) and deposition of $\mathrm{N}$ and $\mathrm{S}$ at our 10 sites. The weighted average wind direction at Fort McMurray is southerly and the prevailing wind directions are east to eastsoutheasterly (from Walmsley \& Bagg 1978). We found no significant correlations between vectors of distance from Syncrude multiplied by the deviation of our site bearings (Tab. 1) from the average or prevailing wind direction bearing (in absolute value) with $\mathrm{N}$ and $\mathrm{S}$ deposition at our 10 sites.

Neither S. fuscum linear growth nor S. fuscum NPP were significantly correlated with growing season deposition of $\mathrm{NH}_{4}{ }^{+}-\mathrm{N}, \mathrm{NO}_{3}{ }^{-}-\mathrm{N}$, TIN, or $\mathrm{SO}_{4}{ }^{2-}-\mathrm{S}$ (Fig. 6). We used stepwise regression to evaluate the effects of monthly (May-September) temperature and precipitation, growing season mean temperature, and growing season total precipitation on $S$. fuscum linear growth or NPP. Both linear growth and NPP were positively related to only August precipitation $(p=0.0006$ and $p=$ 0.0383 , respectively, but August precipitation explained only $0.5 \%$ and $0.2 \%$ of the variation in linear growth and NPP, respectively. In 2005, 2006, 2007, and 2008 August precipitation was 85, 41, 78, and $128 \mathrm{~mm}$ (mean August precipitation from 1971-2000 was $72.7 \mathrm{~mm}$ ), respectively. Averaged across all sites (means \pm standard errors; $n=612$ ), linear growth was $11.5 \pm 0.3$, $11.2 \pm 0.3,11.7 \pm 0.3$, and $12.9 \pm 0.4 \mathrm{~cm}$, respectively, and NPP was $248 \pm 7,239 \pm 6,250 \pm 6$, and $259 \pm 9 \mathrm{~g}$ $\mathrm{m}^{-2} \mathrm{y}^{-1}$ respectively. 


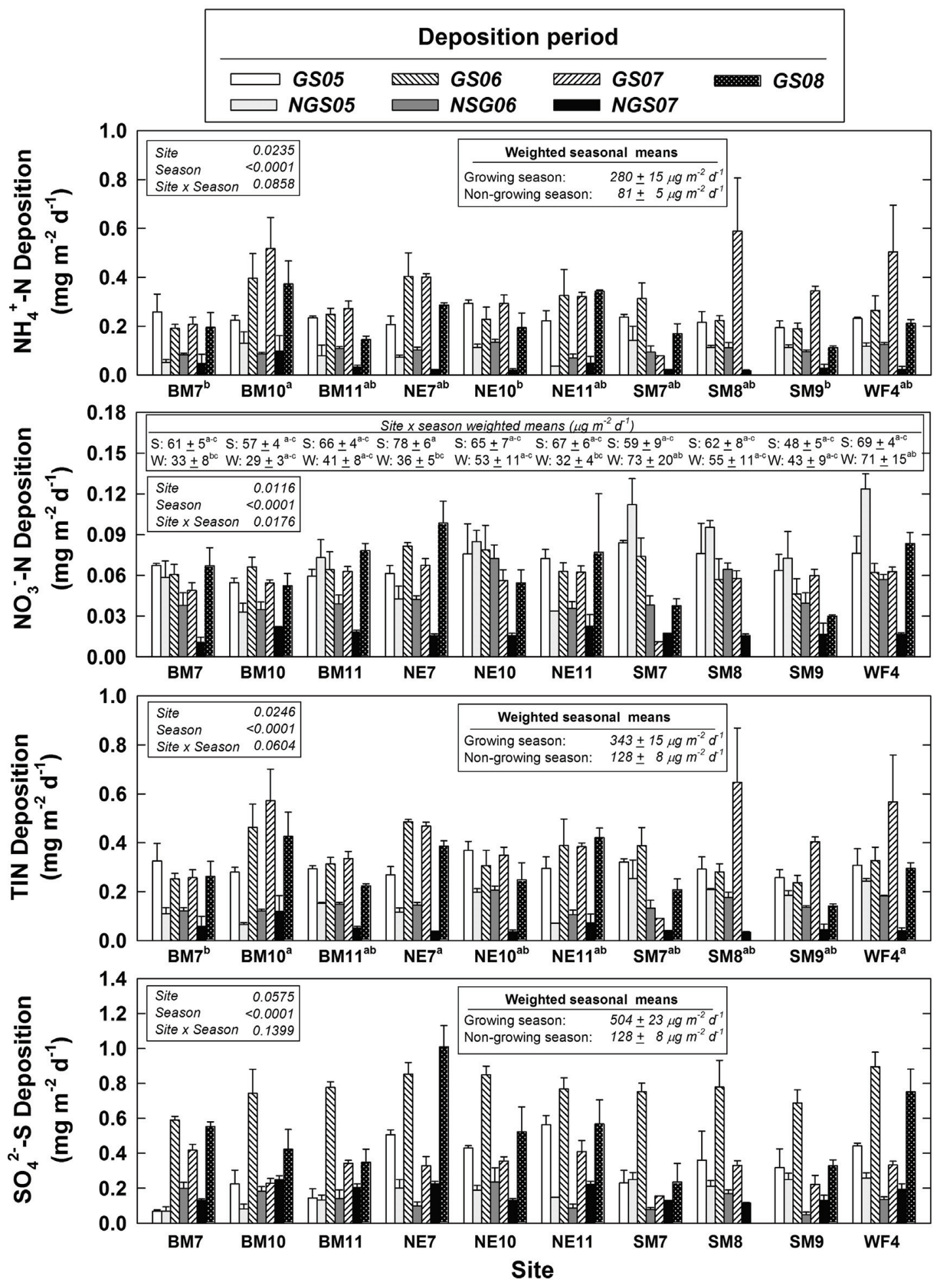

Fig. 5. Deposition of $\mathrm{NH}_{4}{ }^{+}-\mathrm{N}, \mathrm{NO}_{3}^{-}-\mathrm{N}$ TIN $\left(\mathrm{NH}_{4}{ }^{-}-\mathrm{N}\right.$ plus $\left.\mathrm{NO}_{3}{ }^{-}-\mathrm{N}\right)$ and $\mathrm{SO}_{4}{ }^{2-}-\mathrm{S}$ from ion exchange resin collectors. Values are means \pm standard errors $(n=1-5)$. Data were analyzed using weighted (by number of days that each batch of resins was in the field) ANOVA, with collections dates categorized into growing season (GS; exactly corresponding to the duration of NPP measurements in Fig. 4) and non-growing season (NGS); a posteriori comparisons to assess the site $\mathrm{x}$ season interaction for $\mathrm{NO}_{3}{ }^{-}-\mathrm{N}_{\text {were }}$ conducted using Tukey's Honestly Significant Difference test, while a posteriori comparisons of site means for $\mathrm{NH}_{4}{ }^{+}-\mathrm{N}$ and $\mathrm{TIN}$ were conducted using a least significant difference approach with a comparisonwise $\alpha=0.05$ (Tukey's HSD failed to reveal any site differences). For these a posteriori tests, mean values with the same letter superscript do not differ significantly. When a significant season effect with no interaction was obtained, seasonal means are shown. No data were obtained for site SM8 for the growing season of 2008 . 
Tab. 1. Site locations and distance and bearing from Syncrude mine site facilities, $40 \mathrm{~km}$ north of Fort McMurray $\left(57^{\circ} 01^{\prime} \mathrm{N} ; 111^{\circ} 38^{\prime} \mathrm{W}\right)$.

\begin{tabular}{lcccc}
\hline Site Name & Latitude (N) & Longitude (W) & $\begin{array}{c}\text { Distance from Syncrude } \\
\text { Mine Site Facilities (km) }\end{array}$ & $\begin{array}{c}\text { Bearing from Syncrude } \\
\text { Mine Site Facilities }\end{array}$ \\
\hline BM7 & $58^{\circ} 03.545^{\prime}$ & $112^{\circ} 16.486^{\prime}$ & 112.1 & $341^{\circ} 43^{\prime}$ \\
BM10 & $57^{\circ} 19.032^{\prime}$ & $112^{\circ} 23.840^{\prime}$ & 56.9 & $305^{\circ} 58^{\prime}$ \\
BM11 & $57^{\circ} 41.514^{\prime}$ & $111^{\circ} 54.455^{\prime}$ & 76.9 & $347^{\circ} 39^{\prime}$ \\
NE7 & $57^{\circ} 8.810^{\prime}$ & $110^{\circ} 51.809^{\prime}$ & 48.7 & $72^{\circ} 42^{\prime}$ \\
NE10 & $56^{\circ} 37.600^{\prime}$ & $110^{\circ} 11.800^{\prime}$ & 97.6 & $116^{\circ} 23^{\prime}$ \\
NE11 & $57^{\circ} 17.500^{\prime}$ & $111^{\circ} 14.000^{\prime}$ & 39.0 & $39^{\circ} 16^{\prime}$ \\
SM7 & $55^{\circ} 40.870^{\prime}$ & $111^{\circ} 49.610^{\prime}$ & 149.0 & $184^{\circ} 35^{\prime}$ \\
SM8 & $56^{\circ} 12.600^{\prime}$ & $111^{\circ} 12.000^{\prime}$ & 93.5 & $163^{\circ} 32^{\prime}$ \\
SM9 & $56^{\circ} 12.600^{\prime}$ & $111^{\circ} 15.110^{\prime}$ & 92.7 & $165^{\circ} 25^{\prime}$ \\
WF4 & $57^{\circ} 8.887^{\prime}$ & $111^{\circ} 59.029^{\prime}$ & 25.7 & $304^{\circ} 35^{\prime}$ \\
\hline
\end{tabular}

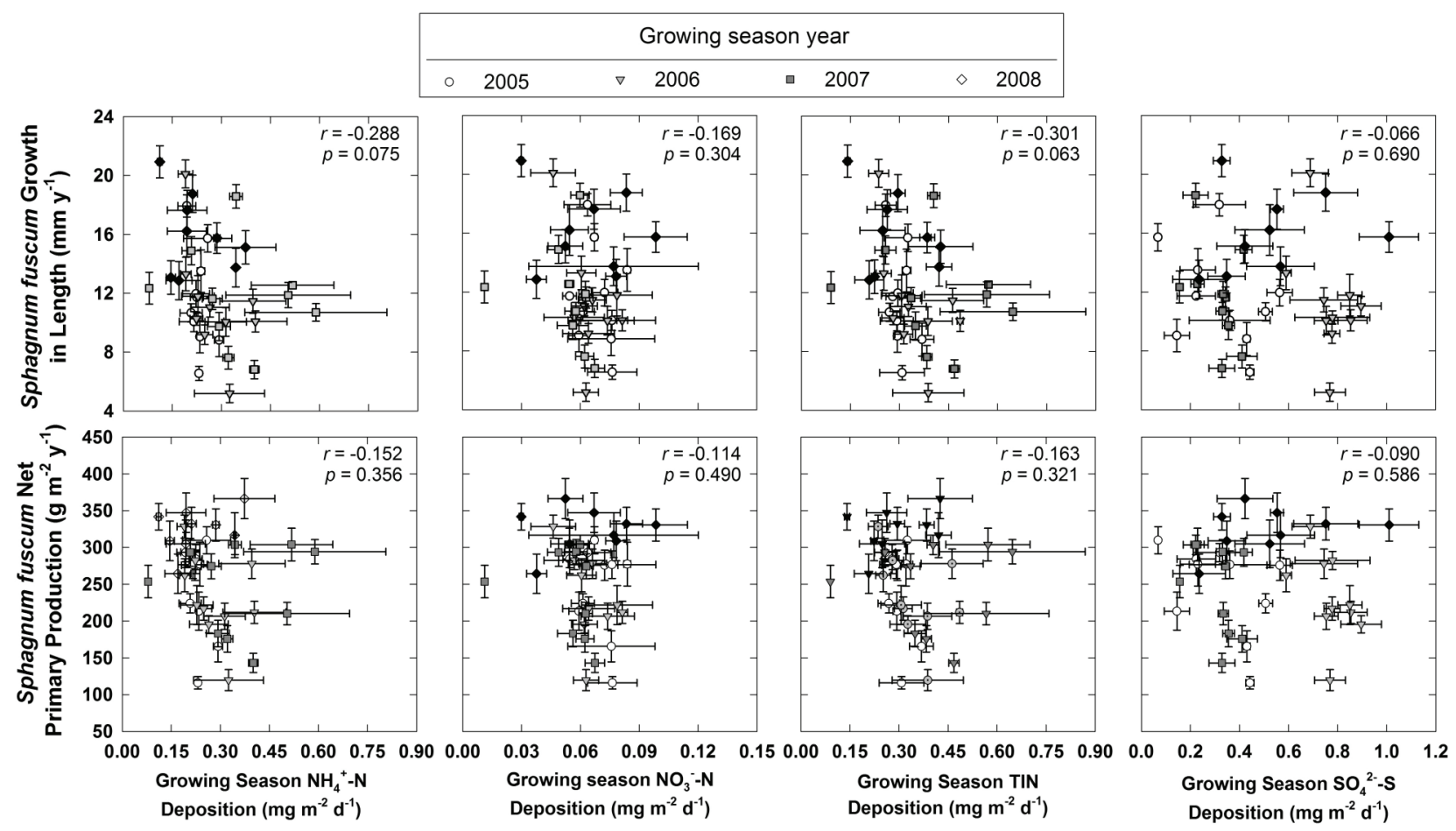

Fig. 6. Correlations between $S$. fuscum vertical growth or NPP with growing season $\mathrm{NH}_{4}{ }^{+}-\mathrm{N}, \mathrm{NO}_{3}{ }^{-}-\mathrm{N}, \mathrm{TIN}\left(\mathrm{NH}_{4}{ }^{+}-\mathrm{N}\right.$ plus $\left.\mathrm{NO}_{3}{ }^{-}-\mathrm{N}\right)$, and $\mathrm{SO}_{4}{ }^{2-}-\mathrm{S}$ deposition. Values are means \pm standard errors. Pearson correlation coefficients $(r)$ were corrected for attenuation due to errors in both growth and deposition variables (van Belle et al. 2004) using the ratios of the pooled standard deviations to the overall mean for each variable.

\section{DISCUSSION}

Emissions of $\mathrm{NO}_{\mathrm{x}}$ and $\mathrm{SO}_{2}$ from development of the oil sands resource on the AOSR ultimately return to regional ecosystems via atmospheric deposition. As summarized by Schindler et al. (2006), background N deposition in the AOSR was less than $2 \mathrm{~kg} \mathrm{ha}^{-1} \mathrm{y}^{-1}$ prior to oil sands development, but as development proceeds, $\mathrm{N}$ deposition may increase to as high as $66 \mathrm{~kg} \mathrm{ha}^{-1} \mathrm{y}^{-1}$ in areas near to the oil sands activity (Allen 2004), and may exceed $20 \mathrm{~kg} \mathrm{ha}^{-1} \mathrm{y}^{-1}$ over thousands of square kilometres (Anonymous 2000, cited in Schindler et al. 2006). At the same time, $\mathrm{SO}_{\mathrm{x}}$ emissions from the oil sands sector in Alberta are predicted to increase from about $90,000 \mathrm{t} \mathrm{y}^{-1}$ to over $160,000 \mathrm{t} \mathrm{y}^{-1}$ in 2015 (Alberta Environment 2008), so an attendant increase in S deposition across the AOSR is expected, as well. As Schindler et al. (2006) note, predictions of present and future deposition have been derived from modelling efforts and have not been verified by direct measurements.

Our ion exchange resins, placed in the open away from the influence of the black spruce canopy, quantified bulk deposition of inorganic ionic forms of $\mathrm{N}$ and $\mathrm{S}$ directly onto S. fuscum hummocks. Our N deposition values (Fig. 5) are consistent with previously reported model estimates of low background $\mathrm{N}$ deposition (cf. Vitt et al. 2003). One exception is that Vitt et al. (2003) reported modelled N deposition for the Steepbank area, 
west northwest of Fort McMurray (bearing $305^{\circ}$ ), of $4.04 \mathrm{~kg} \mathrm{~N} \mathrm{ha}^{-1} \mathrm{y}^{-1}$; the Steepbank site is about the same distance from the Syncrude mine site facilities as our WF4 site, but is east-southeast of Syncrude (bearing of $\left.123^{\circ}\right)$. Jeffries et al. (2003) synthesized measured $\mathrm{NO}_{3}^{-}$$\mathrm{N}$ deposition values for western Canada, reporting values of $<2 \mathrm{~kg} \mathrm{NO}_{3}{ }^{-} \mathrm{ha}^{-1} \mathrm{y}^{-1}\left(<0.45 \mathrm{~kg} \mathrm{NO}_{3}^{-}-\mathrm{N} \mathrm{ha}^{-1} \mathrm{y}^{-1}\right)$ for most of the area west of Manitoba. McDonald et al. (1996) reported wet S deposition in Fort McMurray as $1.8 \mathrm{~kg} \mathrm{ha}^{-1} \mathrm{y}^{-1}$ (measured) and 1.2-1.3 kg ha $\mathrm{y}^{-1}$ (modelled), and modelled dry deposition of $<1$ to $5 \mathrm{~kg} \mathrm{ha}^{-1} \mathrm{y}^{-1}$ across the AOSR region. We found no significant correlations between $\mathrm{N}$ or $\mathrm{S}$ deposition and distance from the heart of the oil sands mining area (the Syncrude mine site facilities) and/or prevailing wind direction. Our low values for $\mathrm{N}$ and $\mathrm{S}$ deposition suggest that elevated deposition from mining activity is restricted to areas closer to and/or immediately downwind of the active mine sites.

Published Sphagnum NPP values range from 9-1450 $\mathrm{g} \mathrm{m}^{-2} \mathrm{y}^{-1}$ and average $259 \mathrm{~g} \mathrm{~m}^{-2} \mathrm{y}^{-1}$ (Gunnarsson et al. 2005). Our overall value for Sphagnum fuscum NPP of $234 \pm 3.3 \mathrm{~g} \mathrm{~m}^{-2} \mathrm{y}^{-1}$ (Fig. 4) is comparable to other measurements in northern Alberta (ranging from $64 \pm 79$ to $245 \pm 147 \mathrm{~g} \mathrm{~m}^{-2} \mathrm{y}^{-1}$; summarized in Vitt et al. 2003), with the exception of a value of $600 \pm 462 \mathrm{~g} \mathrm{~m}^{-2} \mathrm{y}^{-1}$ for the Steepbank site, which also has a modelled elevated N deposition. Neither Sphagnum fuscum vertical growth nor NPP was correlated with deposition of N or S (Fig. 6). Lamers et al. (2000) suggested that at low atmospheric N deposition, Sphagnum NPP is N-limited and therefore increasing $\mathrm{N}$ deposition should result in increasing NPP without an increase in plant tissue N concentrations. Overall, our $\mathrm{N}$ and $\mathrm{S}$ deposition values are quite low and typical of unpolluted areas. Across our 10 sites, the ranges of both annual $\mathrm{N}$ deposition (weighted averages across all resin collection dates of $0.64 \pm 0.07 \mathrm{~kg} \mathrm{ha}^{-1} \mathrm{y}^{-1}$ at BM11 to $0.93 \pm 0.15 \mathrm{~kg} \mathrm{ha}^{-1}$ $\mathrm{y}^{-1}$ at WF4) and growing season $\mathrm{N}$ deposition (weighted averages across all resin collection dates of $0.26 \pm 0.03$ $\mathrm{mg} \mathrm{m} \mathrm{y}^{-1}$ at SM9 to $0.43 \pm 0.05 \mathrm{mg} \mathrm{m}^{-2} \mathrm{y}^{-1}$ at BM10) were narrow. Similarly narrow across-site ranges were obtained for both annual S deposition $(0.92 \pm 0.15 \mathrm{~kg}$ $\mathrm{ha}^{-1} \mathrm{y}^{-1}$ at SM9 to $1.48 \pm 0.26 \mathrm{~kg} \mathrm{ha}^{-1} \mathrm{y}^{-1}$ at NE7) and growing season $\mathrm{S}$ deposition $\left(1.41 \pm 0.02 \mathrm{mg} \mathrm{m}^{-2} \mathrm{y}^{-1}\right.$ at SM9 to $2.47 \pm 0.03 \mathrm{mg} \mathrm{m}^{-2} \mathrm{y}^{-1}$ at NE11). If $S$. fuscum NPP is affected by either $\mathrm{N}$ or $\mathrm{S}$ deposition, a wider gradient of deposition values may be needed to reveal responses.

The Canadian Prairie Provinces are susceptible to periodic drought, which can extend north of the agricultural areas to Fort McMurray (Khandekar 2004). Our study was conducted during years that were warmer and drier than the long-term averages (for 2005, 2006, 2007, 2008 , total annual precipitation was $91,81,78$, and $89 \%$ of normal, respectively, and mean annual temperature was 2.9, 3.0, 1.0 and $0.2{ }^{\circ} \mathrm{C}$ higher than normal; Fig. 2).
It is possible $S$. fuscum growth does respond to variation in $\mathrm{N}$ and/or $\mathrm{S}$ deposition, but that such responses are manifested only in years with normal or cooler, wetter climatic conditions.

Finally, ${ }^{210} \mathrm{~Pb}$ dating of peat from bogs in Alberta (Burke-Scoll 2008) and across eastern Canada (Moore et al. 2004) has indicated that accumulation of $\mathrm{N}$ in peat is several-fold higher than can be accounted for by precipitation inputs, implying an unidentified source or sources of $\mathrm{N}$ to peat. Possible sources of $\mathrm{N}$ include dry deposition, deposition of organic $\mathrm{N}$ compounds, pollen, or biological $\mathrm{N}_{2}$-fixation, but any relationships between these additional $\mathrm{N}$ inputs and $S$. fuscum growth remain unresolved.

\section{CONCLUSION}

Across our 10 study sites, we found no evidence for elevated $\mathrm{N}$ or $\mathrm{S}$ deposition, no consistent site differences in $\mathrm{N}$ or $\mathrm{S}$ deposition, no consistent site differences in Sphagnum fuscum growth, and no relationships between either N or S deposition and S. fuscum growth. We show a significant, but weak, relationship indicating that $S$. fuscum linear growth and NPP is positively related to August precipitation. Our data provide a valuable benchmark of background values for monitoring purposes in anticipation of increasing $\mathrm{N}$ and $\mathrm{S}$ deposition over a broader geographic region within the AOSR.

\section{ACKNOWLEDGMENTS}

This work was supported by the Cumulative Environmental Management Association (CEMA), $\mathrm{NO}_{x} \mathrm{SO}_{2}$ Working Group (CEMA Grant Number: 2004-0034), to R.K. Wieder, D.H. Vitt, M.A. Vile. Helicopter transportation to field sites was provided by Alberta Environment. We thank Brian Benscoter, Rose Bloise, Sara Koropchak, Avni Malhotra, Preston McEachern, Katherine Speicher, Amanda Vaupel, Sandi Vitt, and Bin Xu for field and laboratory assistance.

\section{REFERENCES}

Alberta Environment. 2008. Alberta air emissions: trends and projections. Alberta Environment Information Centre, Edmonton, AB.

Alberta Environmental Protection. 1994. Natural regions and subregions of Alberta. 1:1,000,000 scale map. Land Information Services. Edmonton, AB.

Allen, E. 2004. Effects of nitrogen deposition on forests and peatlands: a literature review and discussion of the potential impacts of nitrogen deposition in the Alberta Oils Sands Region. Wood Buffalo Environmental Association, Fort McMurray, AB.

Belland, R.J. \& D.H. Vitt. 1995. Bryophyte vegetation patterns along environmental gradients in continental bogs. Écoscience, 2: 395-407.

Berendse, F., N. van Breemen, H. Rydin, A. Buttler, M.M.P.D. Heijmans, M.R. Hoosbeek, J.A. Lee, E. Mitchell, T. Saarinen, H. Vasander \& B. Wallén. 2001. Raised atmospheric $\mathrm{CO}_{2}$ levels and increased $\mathrm{N}$ deposition cause shifts in plant species composition and production in Sphagnum bogs. Global Change Biol., 7: 591-598. 
Burke-Scoll, M. 2008. Nitrogen and sulphur inputs and accumulations in continental ombrotrophic peatland ecosystems in Alberta, Canada. M.S. thesis, Villanova University, Villanova, PA.

CEMA: $\mathrm{NO}_{x} \mathrm{SO}_{2}$ Management Working Group. 2005. $N O_{x}$ dispersion and chemistry assumptions in the CALPUFF model. http://www.cemaonline.ca/index.php/component/ docman/doc_download/513-nox-dispersion-and-chemistry -assumptions-in-the-calpuff-model.

Clymo, R.S. 1970. The growth of Sphagnum: Methods of measurement. J. Ecol., 58: 13-49.

EPCM Associated ${ }^{\mathrm{Ltd}}$. 2002. Estimation of dry acid deposition at TEEM passive monitoring sites. - Submitted to Wood Buffalo Environmental Association - wbea.org/ component/option,com_docman/task,doc_details/gid,47/It emid, $104 /$.

Fenn, M.E. \& M.A. Poth. 2004. Monitoring nitrogen deposition in through fall using ion exchange resin columns. A field test in the San Bernardino Mountains. J. Environ. Qual., 33: 2007-2014.

Fenn, M.E., T. Blubaugh, D. Alexander \& D. Jones. Undated. Using ion exchange resins to monitor throughfall and bulk deposition to forests. http://www.fs.fed.us/psw/topics/ air quality/resin collectors/fenn iermethods.pdf.

Ferguson, P. \& J.A. Lee. 1979. The effects of bisulphite and sulphate upon photosynthesis in Sphagnum. New Phytol., 82: 703-712

Ferguson, P. \& J.A. Lee. 1980. Some effects of bisulphate and sulphate on the growth of Sphagnum in the field. Environ. Pollut., 21: 58-71.

Ferguson, P., J.A. Lee \& J.N. Bell. 1978. Effects of sulphur pollution on the growth of Sphagnum species. Environ. Pollut. 16: 151-162.

Gauci, V., N. Dise \& D. Fowler. 2002. Controls on suppression of methane flux from a peat bog subjected to simulated acid rain sulphate deposition. Global Biogeochem. Cycles, 16: 1-12.

Gauci, V., E. Matthews, N. Dise, B. Walter, D. Koch, G. Granberg \& M. Vile. 2004. Sulphur pollution suppression of the wetland methane source in the $20^{\text {th }}$ and $21^{\text {st }}$ Centuries. Proc. Natl. Acad. Sci. USA, 101: 12583-12587.

Gauci, V. \& S.J. Chapman. 2006. Simultaneous inhibition of $\mathrm{CH}_{4}$ efflux and stimulation of sulphate reduction in peat subject to simulated acid rain. Soil Biol. Biochem., 38: 3506-3510.

Golder Associates. 2003. Report on evaluation of historic and future acid deposition effects on soils in the Athabasca Oil Sands region. $\mathrm{NO}_{\mathrm{x}}-\mathrm{SO}_{2}$ Management Working Group CEMA, Edmonton, AB.

Gunnarsson, U. 2005. Global patterns of Sphagnum productivity. J. Bryol., 27: 269-279.

Hemond, H.F. 1980. Biogeochemistry of Thoreau's Bog, Concord, Massachusetts. Ecol. Monogr., 50: 507-526.

Jeffries, D.S., T.A. Clair, S. Couture, P.J. Dillon, J. Dupont, W. Keller, D.K. McNicol, M.A. Turner, R. Vet \& R. Weber. 2003. Assessing the recovery of lakes in southeastern Canada from the effects of acid deposition. Ambio, 32: 176-182.

Khandekar, M.L. 2004. Canadian prairie drought: A climatological assessment. Alberta Environment, Environmental Policy Branch, Alberta Environment Information Centre, Edmonton, AB.

Lamers, L.P.M., R. Bobbink \& J.G.M. Roelofs. 2000. Natural nitrogen filter fails in raised bogs. Global Change Biol., 6: 583-586.

Limpens, J. \& F. Berendse. 2003. How litter quality affects mass loss and N loss from decomposing Sphagnum. Oikos, 103: 537-547.

Limpens, J., F. Berendse \& H. Klees. 2003. N deposition affects $\mathrm{N}$ availability in interstitial water, growth of
Sphagnum and invasion of vascular plants in bog vegetation. New Phytol., 157: 339-347.

Limpens, J., M.M.P.D. Heijmans \& F. Berendse. 2006. The nitrogen cycle in boreal peatlands. In: R.K. Wieder \& D.H. Vitt (Eds), Boreal Peatland Ecosystems. Ecological Studies 188, Springer, Berlin: 195-230.

McDonald, K.M., L. Cheng, M.P. Olson \& R.P. Angle. 1996. A comparison of box and plume model calculations for sulphur deposition and flux in Alberta, Canada. Atmos. Environ., 30: 2969-2980.

Moore, R., C. Blodau, J. Turunen, N. Roulet \& R.J.H. Richard. 2004. Patterns of nitrogen and sulphur accumulation and retention in ombrotrophic bogs, eastern Canada. Global Change Biol., 11: 356-367.

Press, M.C., S. Woodin \& J.A. Lee. 1986. The potential importance of an increased atmospheric nitrogen supply to the growth of ombrotrophic Sphagnum species. New Phytol., 103: 45-55.

Schindler, D.W., P.J. Dillon \& H. Schreier. 2006. A review of anthropogenic sources of nitrogen and their effects on Canadian aquatic ecosystems. Biogeochem., 79: 25-44.

Taylor, G. 1981. Oil sands development and acid rain in Alberta. Alternatives, 9: 3-9.

Turetsky, M.R., S. Crow, R.J. Evans, D.H. Vitt \& R.K. Wieder. 2008. Tradeoffs in resource allocation among moss species control decomposition in boreal peatlands. $J$. Ecol., 96: 1297-1305.

van Belle, G., L.D. Fisher, P.J. Heagerty \& T. Lumley. 2004. Biostatistics, A methodology for the health sciences, Second Ed. Wiley-Interscience: 894 pp.

Vile, M.A. \& M. Novák. 2006. Sulphur cycling in boreal peatlands: From acid rain to global climate change. In: R.K. Wieder \& D.H. Vitt (Eds), Boreal peatland ecosystems. Ecological Studies 188. Springer, Berlin: 259-287.

Vile, M.A., S. Bridgham \& R.K. Wieder. 2003a. Response of anaerobic carbon mineralization rates to sulphate amendments in a boreal peatland. Ecol. Appl., 13: 720-734.

Vile, M.A., S. Bridgham, R.K. Wieder \& M. Novák. 2003 b. Atmospheric sulphur deposition alters pathways of gaseous C production in peatlands. Global Biogeochem. Cycles, 17:1058. DOI 10.1029/2002GB001966.

Vile, M.A., K. Scott, E. Brault, K. Wieder \& D. Vitt. (2010). Living on the edge: The effects of drought on Canada's western boreal peatlands. In: N. Slack \& Z. Tuba (Eds), Bryophyte ecology and climate change, Cambridge University Press: (in press).

Vitt, D.H. 2000. Peatlands: Ecosystems dominated by bryophytes. In: A.J. Shaw \& B. Goffinet (Eds), Bryophyte biology, Cambridge University Press, Cambridge: 312-343.

Vitt, D.H. 2006. Functional characteristics and indicators of boreal peatlands. In: R.K. Wieder \& D.H. Vitt (Eds), Boreal peatland ecosystems, Ecological Studies 188, Springer, Berlin: 9-24.

Vitt, D.H. 2007. Estimating ground layer net primary production in tundra, peatlands, and forests. In: T. Fahey (Ed.), Principles and standards for measuring net primary productivity in long-term ecological studies. Oxford Press, Oxford: 82-105.

Vitt, D.H. 2008. Peatlands. In: S.E. Jorgensen \& B. Faith (Eds). Encyclopedia of ecology. Elsevier, Oxford: 2656-2664.

Vitt, D.H., Y. Li \& R.J. Belland. 1995. Patterns of bryophyte diversity in peatlands of continental western Canada. The Bryologist, 98: 218-227.

Vitt, D.H., L.A. Halsey, M.N. Thormann \& T. Martin. 1996. Peatland inventory of Alberta phase I: overview of peatland resources in the natural regions and subregions of the province. Sustainable Forest Management Network, Edmonton, AB.

Vitt, D.H., R.K. Wieder, L.A. Halsey \& M. Turetsky. 2003. Response of Sphagnum fuscum to nitrogen deposition: A 
case study of ombrogenous peatlands in Alberta, Canada. The Bryologist, 106: 235-245.

Walbridge, M.R. \& J.A. Navaratnam. 2006. Phosphorus in boreal peatlands, In: R.K. Wieder \& D.H. Vitt (Eds), Boreal peatland ecosystems, Ecological Studies 188, Springer, Berlin: 231-259.

Walmsley, J.L. \& D.L. Bagg. 1978. A method of correlating wind data between two stations with application to the Alberta oil sands. Atmos. Ocean, 16: 333-347.

Wieder, R.K. 2006. Primary production in boreal peatlands. In: R.K. Wieder \& D.H. Vitt (Eds), Boreal peatland ecosystems. Ecological Studies 188, Springer, Berlin: 145-164.
Wieder, R.K. \& D.H. Vitt. 2006. Boreal peatland ecosystems, Ecological Studies 188, Springer, Berlin: 448 pp.

Wieder, R.K., J.B. Yavitt \& J.E. Lang. 1990. Methane production and sulphate reduction in two Appalachian peatlands. Biogeochem., 10: 81-104.

Woodin, S.J., M.C. Press \& J.A. Lee. 1985. Nitrate reductase activity in Sphagnum fuscum in relation to wet deposition of nitrate from the atmosphere. New Phytol., 99: 381-388. 